\title{
Studi Literatur: Kesulitan Siswa Pada Pembelajaran Kimia SMA Topik Sel Volta
}

\author{
Nursida Sutantri ${ }^{1 *}$ \\ ${ }^{1}$ Program Studi Magister Pendidikan Kimia, Universitas Pendidikan Indonesia \\ *nursidasutantri@upi.edu
}

ARTICLE HISTORY

Revised: 19 February 2022
Accepted: 24 February 2022

\begin{abstract}
ABSTRAK
Sel volta merupakan salah satu konsep kimia pada kelas XII SMA yang memerlukan kemampuan siswa dalam mengintegrasikan level makroskopik, submikroskopik dan simbolik agar mendapatkan pemahaman yang utuh. Tantangan mengintegrasikan tiga level representasi tersebut menjadi salah satu penyebab ditemukannya miskonsepsi dan kesulitan belajar yang dialami oleh siswa. Miskonsepsi dan kesulitan yang dialami siswa antara lain dalam konsep aliran listrik dalam sel volta, elektroda pada sel galvani, potensial elektroda dan potensial sel. Untuk mengatasi miskonsepsi dan kesulitan pada materi sel volta tersebut sudah dilakukan berbagai upaya, diantaranya penerapan pembelajaran dengan perubahan konseptual untuk mereduksi miskonsepsi dan penggunaan visualisasi dalam bentuk media animasi, gambar dan video menjadi upaya untuk mengatasi kesulitan yang dialami siswa dalam memahami konsep sel volta. Berdasarkan hal tersebut, maka pembelajaran pada konsep sel volta perlu memperhatikan strategi pembelajaran dan media yang dapat memfasilitasi tiga level representasi pada konsep sel volta.

Kata kunci : sel volta, representasi, miskonsepsi, visualisasi
\end{abstract}

ABSTRACT

High School Chemistry Learning Problems on the topic of Voltaic Cells. The voltaic cell is one of the chemical concepts in XII grade which requires students' ability to integrate macroscopic, submicroscopic and symbolic levels in order to get a complete understanding. The challenge of integrating the three levels of representation is one of the causes of the discovery of misconceptions and learning difficulties experienced by students. The misconceptions and difficulties experienced by students include the concept of electric current in a voltaic cell, electrodes in a galvanic cell, electrode potential and cell potential. To overcome the misconceptions and difficulties in the voltaic cell material, various efforts have been made, including the application of learning with conceptual changes to reduce misconceptions and the use of visualization in the form of animation, images and videos as an effort to overcome the difficulties experienced by students in understanding the voltaic cell concept. Based on this, learning on the voltaic cell concept needs to pay attention to learning strategies and media that can facilitate three levels of representation on the voltaic cell concept.

Key word: Voltaic cell, representation, misconception, visualization

\section{Pendahuluan}

Sel volta merupakan salah satu konsep Kimia pada tingkat SMA yang dipelajari oleh siswa kelas XII. Materi ini memiliki karakteristik yang memerlukan kemampuan dalam mengintegrasikan tiga level representasi yaitu makroskopik, submikroskopik dan simbolik karena cenderung bersifat abstrak dan kompleks (Helsy, Maryamah, Farida, \& Ramdhani, 2017). Representasi makroskopis dapat diperoleh melalui pengamatan dari suatu fenomena yang dapat terlihat dan dirasakan oleh indera secara nyata dan langsung, misalnya endapan dan voltase yang dihasilkan dalam suatu percobaan sel volta. Representasi submikroskopis berkaitan erat dengan penjelasan pada tingkat partikel (atom, molekul dan ion), misalnya pergerakan ion dan elektron. Sedangkan representasi simbolik yaitu bahasa simbolik seperti persamaan reaksi redoks yang terjadi pada suatu sel volta. Pada umumnya siswa menghadapi kesulitan dalam memvisualisasikan dan menghubungkan apa yang terjadi pada tingkat submikroskopik (tingkat molekul) terhadap pengamatan makroskopis (pengamatan eksperimen) dan tingkat simbolis, sehingga konsep sel Volta tidak dapat dipahami secara utuh (Supasorn, 2015).

Karakteristik konsep sel volta tersebut menjadi salah satu kesulitan siswa dalam memahami konsep antara lain pada konsep peran jembatan garam dalam sel volta, proses terjadinya reaksi oksidasi dan reduksi pada sel volta, konsep potensial elektroda reduksi standar, jenis elektroda dan 
penentuan setengah reaksi sel serta pada perhitungan harga potensial sel (LIN, YANG, CHIU, \& CHOU, 2002). Data lain menyebutkan bahwa kesulitan siswa dalam mengerjakan soal-soal yang berkaitan dengan pergerakan elektron (Yunita, 2014).

Berkaitan dengan karakteristik materi sel volta serta kesulitan yang dialami oleh siswa dalam mempelajarinya, perlu adanya telaah terhadap materi sel volta serta upaya untuk mengatasi problematika tersebut. Upaya tersebut antara lain penggunaan conceptual change texts (perubahan teks konseptual) dalam mengajar yang dikombinasikan dengan metode pengajaran yang bersifat konstruktivistik (Dorsah \& Yaayin, 2019). Salah satu strategi belajar yang bersifat konstruktivistik yaitu POE (Predict, Observe and Explain) (Karamustafaoğlu \& Mamlok-Naaman, 2015). Selain itu penggunaan bahan ajar yang yang dapat memvisualisasikan hal-hal abstrak serta menampilkan triple representasi dalam topik sel volta dapat membantu pemahaman siswa (Rokhim, Syafruddin, \& Widarti, 2020).

\section{Metode}

Penulisan artikel ini menggunakan metode studi literatur mengenai bebrbagai problematika pembelajaran kimia pada materi sel volta. Literatur yang digunakan terdiri dari berbagai artikel yang dipublikasikan pada jurnal nasional dan internasional. Hasil dari studi literatur ini dianalisis dan disimpulkan menjadi sebuah temuan mengenai problematika pembelajaran kimia pada materi sel volta. Problematika pembelajaran kimia pada sel volta selanjutnya dicarikan solusi berupa gagasan pembelajaran kimia yang bisa diterapkan untuk mengatasi setiap problematika pembelajaran sel volta yang bisa ditemui oleh para guru.

\section{Hasil dan Pembahasan}

\section{Jenis-Jenis Miskonsepsi Siswa Pada Topik Sel Volta}

Sel Volta merupakan bagian dari konsep kimia yang bersifat abstrak sehingga memungkinkan siswa mengalami kesulitan dalam memahami konsep sehingga terbentuk pemahaman yang salah. Apabila hal tersebut terjadi secara konsisten maka akan dapat menimbulkan terjadinya kesalahan konsep atau miskonsepsi (Berg, 1991). Miskonsepsi yaitu kesalahan yang terjadi pada siswa ketika memahami suatu konsep yang tidak sesuai secara ilmiah (Treagust, 2006). Miskonsepsi ini akan menghambat siswa dalam menerima pengetahuan yang baru sehingga akan menghambat ketercapaian keberhasilan dalam proses pembelajaran (Artiawati, Mulyani, \& Kurniawan, 2018).

Berikut ini adalah tabel yang berisi miskonsepsi-miskonsepsi pada topik sel volta berdasarkan penelitian-penelitian terdahulu dalam jurnal (Asnawi, Effendy, \& Yahmin, 2017):

Tabel 1. Miskonsepsi Pada Topik Sel Volta

\begin{tabular}{|c|c|c|}
\hline No. & Miskonsepsi & Sumber \\
\hline 1. & $\begin{array}{l}\text { Elektron memasuki larutan dari katode, } \\
\text { bergerak dalam larutan dan melalui } \\
\text { jembatan garam bergerak menuju anode } \\
\text { untuk melengkapi sirkuit }\end{array}$ & $\begin{array}{l}\text { Garnett dan Treagust, } \\
\text { 1992b; Sanger dan } \\
\text { Greenbowe, 1997a; 1997b; } \\
\text { Özkaya et al., 2003 }\end{array}$ \\
\hline 2. & $\begin{array}{l}\text { Elektron bergerak dalam larutan tanpa } \\
\text { bantuan dari ion-ion (kation atau anion) }\end{array}$ & $\begin{array}{l}\text { Sanger dan Greenbowe, } \\
\text { 1997a; 1997b. }\end{array}$ \\
\hline 3. & $\begin{array}{l}\text { Elektron bergerak dalam larutan dari satu } \\
\text { ion ke ion yang lain. }\end{array}$ & $\begin{array}{l}\text { Sanger dan Greenbowe, } \\
\text { 1997b. }\end{array}$ \\
\hline 4. & $\begin{array}{l}\text { Dalam tabel potensial reduksi standar, } \\
\text { spesies dengan harga } \mathrm{E}^{\circ} \text { lebih positif adalah } \\
\text { anode. }\end{array}$ & $\begin{array}{l}\text { Garnett } \\
1992 b .\end{array}$ \\
\hline
\end{tabular}




\begin{tabular}{|c|c|c|}
\hline No. & Miskonsepsi & Sumber \\
\hline 5. & $\begin{array}{l}\text { Identifikasi anode dan katode bergantung } \\
\text { pada penempatan fisik setengah sel. }\end{array}$ & $\begin{array}{l}\text { Garnett dan Treagust, } \\
\text { 1992b; Sanger dan } \\
\text { Greenbowe, } \\
\text { Özkaya et al., } 2003\end{array}$ \\
\hline 6. & $\begin{array}{l}\text { Anode seperti anion yang selalu bermuatan } \\
\text { negatif dan katode seperti kation yang selalu } \\
\text { bermuatan positif. }\end{array}$ & $\begin{array}{l}\text { Sanger dan Greenbowe, } \\
\text { 1997a. }\end{array}$ \\
\hline 7. & $\begin{array}{l}\text { Katode adalah tempat terjadinya reaksi } \\
\text { pelepasan elektron. }\end{array}$ & Schmidt et al., 2007. \\
\hline 8. & $\begin{array}{l}\text { Penentuan potensial elektrode suatu spesies } \\
\text { tidak memerlukan setengah sel standar. }\end{array}$ & $\begin{array}{l}\text { Garnett dan } \\
\text { 1992b. }\end{array}$ \\
\hline 9. & $\begin{array}{l}\text { Potensial setengah sel bukan merupakan } \\
\text { sifat intensif. }\end{array}$ & $\begin{array}{l}\text { Sanger dan Greenbowe, } \\
\text { 1997a. }\end{array}$ \\
\hline 10 & $\begin{array}{l}\text { Potensial setengah sel bersifat mutlak dan } \\
\text { dapat digunakan untuk memprediksi } \\
\text { kespontanan reaksi setengah sel }\end{array}$ & $\begin{array}{l}\text { Sanger dan Greenbowe, } \\
\text { 1997a; Özkaya et al., } \\
\text { 2003. }\end{array}$ \\
\hline 11. & $\begin{array}{l}\text { Potensial sel diperoleh } \\
\text { menambahkan secara langsung } \\
\text { reduksi masing-masing elektrode. }\end{array}$ & $\begin{array}{l}\text { Sanger dan Greenbowe, } \\
\text { 1997a. }\end{array}$ \\
\hline
\end{tabular}

\section{Kesulitan Memecahkan Masalah Numerik}

Kemampuan numerik merupakan kemampuan berpikir siswa dalam mengorganisasikan suatu informasi untuk memecahkan masalah yang berkaitan dengan angka yang meliputi kemampuan menghitung dalam hal penjumlahan, pengurangan, perkalian dan pembagian (Irawan \& Kencanawaty, 2016). Kemampuan numerik ini akan mempengaruhi kemampuan siswa dalam menyelesaikan soal hitungan. Ada siswa yang memiliki kemampuan numerik yang tinggi dan rendah. Dimana siswa yang mempunyai kemampuan numerik yang tinggi akan bekerja lebih baik dalam berhitung sedangkan siswa yang mempunyai kemampuan numerik rendah akan mengalami kesulitan dalam berhitung (Cahyono, Masykuri, \& Ashadi, 2016). Kompetensi melakukan perhitungan-perhitungan numerik dalam pembelajaran kimia, misalnya perhitungan stoikiometri, kesetimbangan, termokimia, $\mathrm{pH}$ larutan asam-basa, buffer, hidrolisis, kelarutan, elektrokimia, teridentifikasi sebagai masalah nyata yang dihadapi siswa (Dr. Ida Farida, 2018).

Kemampuan numerik siswa menjadi kendala dalam memvisualisasikan submikroskopik yang terjadi. Hal tersebut juga dikemukakan oleh (Asih, Ibnu, \& Suharti, 2018) bahwa visualisasi representasi submikroskopik yang terjadi dalam sel volta dapat mempermudah pemahaman siswa tentang fenomena elektrokimia tersebut. Selain itu dapat mempermudah memberikan gambaran aliran elektron di dalam larutan elektrolit bermigrasi dari anoda menuju katoda melalui sirkuit tertutup (kabel) (Rokhim, Syafruddin, \& Widarti, 2020).

Kesulitan siswa dalam memecahkan masalah numerik pada topik sel volta ini yaitu pada subtopik potensial reduksi standar dan saat menghitung potensial sel (LIN, YANG, CHIU, \& CHOU, 2002). Hasil penelitian lain menyebutkan bahwa saat siswa menentukan harga potensial sel dari suatu rangkaian sel volta, terdapat siswa yang menjumlahkan potensial reduksi standar pada masing-masing elektroda. Ada siswa yang beranggapan ketika kedua elektroda memiliki harga potensial reduksi standar bernilai negatif, maka tidak terjadi reaksi spontan (Nisa \& Fitriza, 2021). Hal ini menjadi salah satu penyebab kesulitan pada pemecahan masalah numerik topik sel volta. 


\section{Gagasan Mengatasi Kesulitan Siswa Pada Topik Sel Volta}

Berdasarkan hasil penelitian yang telah dilakukan sebelumnya, dihasilkan bahwa beberapa upaya untuk mengatasi kesulitan siswa pada topik sel volta antara lain dengan conceptual change texts (perubahan teks konseptual). Cara ini dapat membantu siswa untuk mengubah konsepsi atau miskonsepsi yang sudah ada sebelumnya menjadi konsep yang dapat diterima secara ilmiah. Studi ini juga mengungkapkan bahwa beberapa miskonsepsi dipegang oleh sejumlah besar siswa bahkan setelah instruksi menggunakan perubahan konseptual teks. Kesalahpahaman yang paling umum diidentifikasi adalah; bahwa fungsi jembatan garam adalah untuk memungkinkan aliran elektron, anoda dalam sel elektrokimia selalu di sebelah kiri, dalam sel elektrokimia elektron bergerak dari satu elektroda ke yang lain melalui jembatan garam, dalam sel elektrokimia anion bergerak dari anoda ke katoda, katoda dalam sel elektrokimia selalu di sebelah kanan, dan dalam sel elektrokimia oksidasi terjadi di katoda dan reduksi di anoda (Dorsah \& Yaayin, 2019).

Hasil penelitian lain menyebutkan bahwa proses pengajaran harus bersifat konstruktivisme, yang salah satu strateginya adalah penggunaan strategi belajar model POE (Predict, Observe and Explain) (Karamustafaoğlu \& Mamlok-Naaman, 2015). Hasil analisis menunjukkan bahwa kemampuan siswa dalam melakukan Prediksi, Observasi, dan Eksplanasi (POE) secara umum mencapai nilai rata-rata 71,60 dan termasuk ke dalam kategori baik. Kemampuan kognitif dalam menghitung potensial sel, mengurutkan daya pereduksi (dari yang paling kuat ke paling lemah), dan menentukan reaksi yang berlangsung tidak spontan berdasarkan gambar rangkaian sel volta, masih tergolong kurang. Adapun faktor-faktor yang mempengaruhi pembelajaran konsep sel volta dengan menggunakan model pembelajaran POE adalah 1) kurangnya penguasaan akan konsep prasyarat tentang reaksi redoks, 2) tidak mampu mengintegrasikan konsep sebelum dan setelah pembelajaran dan, 3) tidak mengenal model pembelajaran ini sebelumnya (Yunita, 2014).

Selain itu penggunaan bahan ajar yang menggunakan teks, gambar dan video yang dapat memvisualisasikan hal-hal abstrak serta menampilkan tripel representasi dalam topik sel volta dapat membantu pemahaman siswa. Penggunaan video pembelajaran mempunyai kekuatan khas dibandingkan teks yang tidak efektif. Video tersebut dapat memvisualisasikan konsep kepada siswa dengan lebih mudah dan interaktif. Video ini dikembangkan untuk mengatasi kendala waktu karena dapat dilihat dimanapun dan kapanpun (Rokhim, Syafruddin, \& Widarti, 2020). Hasil penelitian lain menyebutkan penggunaan bahan ajar yang memfasilitasi kebutuhan belajar Multiple Representation pada Materi Sel Volta dalam bentuk Digital Flipbook dapat menjadi salah satu solusi untuk guru dan siswa agar pembelajaran menjadi lebih menyenangkan dan menarik. Bahan ajar flipbook yang dikembangkan telah direvisi berdasarkan hasil validasi dari validator ahli dan hasil uji coba kelompok melalui Uji keterbacaan kelompok kecil dilakukan pada 50 alumni SMA dengan peminatan IPA (Setiawan, Dasna, \& Muchson, 2020).

Sejalan dengan hasil penelitian diatas, pengembangan multimedia interaktif voltachem pada sub materi pokok sel volta layak digunakan untuk mengurangi miskonsepsi pada materi sel volta. Penggunaan multimedia interaktif dalam pembelajaran ini mampu meningkatkan motivasi belajar siswa dengan cara menyajikan informasi melalui desain tampilan dan isi secara interaktif dan inovatif. Materi dalam multimedia interaktif yang memperhatikan aspek pemrosesan informasi akan lebih mudah dipahami karena mampu mengurangi beban kognitif siswa (Inayati \& Sukarmin, 2014).

Berdasarkan hasil penelitian diatas, terdapat saran pada beberapa penelitian, misalnya pada hasil penelitian penggunaan conceptual change texts, para peneliti menyarankan bahwa teks perubahan konseptual dapat dikombinasikan dengan metode pengajaran konstruktivis lainnya dalam mengajar kimia misalnya model pembelajaran POE, PjBL, PBL, Inkuiri, dll. Pada hasil penelitian penggunaan strategi belajar model POE (Predict, Observe and Explain), terdapat Faktor-faktor yang mempengaruhi kemampuan siswa dalam melakukan prediksi, observasi, dan eksplanasi antara lain adalah kurangnya penguasaan konsep prasyarat tentang reaksi redoks, ketidakmampuan untuk 
mengintegrasikan konsep sebelum dan setelah pembelajaran dan tidak mengenal model pembelajaran ini sebelumnya sehingga sebaiknya model pembelajaran ini dapat digunakan dari sebelum siswa mempelajari materi sel volta. Untuk penelitian penggunaan bahan ajar melalui Voltachem dan Digital Flipbook, peneliti menyarankan perlu penelitian lebih lanjut dengan tahap berikutnya dan menerapkan multimedia interaktif Voltachem dan Digital Flipbook yang telah dikembangkan dalam kegiatan belajar mengajar di kelas dengan jumlah siswa yang sebenarnya.

Berdasarkan beberapa hasil dan saran pada beberapa penelitian tersebut, peneliti memberikan gagasan untuk mengatasi kesulitan siswa pada materi sel volta yaitu penggunaan conceptual change texts dengan dikombinasikan dengan strategi pembelajaran yang bersifat konstruktivistik misalnya model pembelajaran POE (Predict, Observe and Explain). Secara umum, model pembelajaran POE terbagi menjadi tiga tahap yakni : Tahap Predict yaitu siswa mampu memperkirakan suatu kecenderungan atau pola tertentu, misalnya siswa memprediksi reaksi yang terjadi pada beberapa percobaan sel volta, kemudian tahap Observe yaitu siswa mengumpulkan data atau informasi melalui praktikum sehingga siswa dapat melihat fenomena sel volta secara langsung (aspek makroskopis), lalu tahap Explain yaitu siswa menjelaskan secara terperinci secara terperinci disertai dengan alasanalasannya, baik berupa penjelasan secara perhitungan maupun secara molekuler terkait sel volta sehingga siswa dapat mengintegrasikan representasi Kimia yaitu aspek makroskopis, sub mikroskopis dan simbolik.

Pemberian teks pembelajaran dapat peneliti berikan sebelum pembelajaran dimulai sehingga siswa dapat membaca terlebih dahulu sebelum pembelajaran di kelas melalui bahan ajar yang di dalamnya terdapat visualisasi molekul, elektron, dll yang dikemas dalam bentuk Digital Flipbook dilengkapi oleh video-video percobaan dan animasi terkait sel volta.

\section{Simpulan}

Sel volta merupakan salah satu konsep kimia pada kelas XII SMA yang memerlukan kemampuan siswa dalam mengintegrasikan tiga representasi kimia yaitu level makroskopik, submikroskopik dan simbolik agar siswa mendapatkan pemahaman yang utuh. Tantangan tersebut menjadi salah satu penyebab ditemukannya kesulitan belajaran dan miskonsepsi yang dialami oleh siswa. Untuk mengatasi hal tersebut sudah dilakukan berbagai upaya, diantaranya penerapan pembelajaran dengan perubahan konseptual untuk mereduksi miskonsepsi, penggunaan strategi pembelajaran yang bersifat konstruktivistik dan penggunaan bahan ajar yang di dalamnya terdapat visualisasi molekul, elektron, dll. Berdasarkan hal tersebut, maka pembelajaran pada konsep sel volta perlu memperhatikan strategi pembelajaran, bahan ajar dan media yang dapat memfasilitasi tiga level representasi pada konsep sel volta.

\section{Referensi}

Artiawati, P. R., Mulyani, R., \& Kurniawan, Y. (2018). Identifikasi Kuantitas Siswa yang Miskonsepsi Menggunakan Three Tier Test Pada Materi Gerak Lurus Berubah Beraturan. Jurnal Pendidikan Fisika, 5-7.

Asih, F. E., Ibnu, S., \& Suharti. (2018). Pengaruh Karakteristik Representasi Submikroskopik Terhadap Keterampilan Argumentasi Siswa Pada Topik Elektrokimia. Jurnal Pendidikan Kimia, 1-9.

Asnawi, R., Effendy, \& Yahmin. (2017). Kemampuan Berpikir Ilmiah Siswa Dan Miskonsepsi Pada Materi Elektrokimia. Jurnal Ilmu Pendidikan, 25-33.

Cahyono, T. D., Masykuri, M., \& Ashadi. (2016). Kontribusi Kemampuan Numerik Dan Kreativitas Terhadap Prestasi Belajar Siswa Pada Materi Pokok Hidrolisis Kelas Xi Mia1 Dan Xi Mia 5 Sma Negeri 2 Karanganyar. Jurnal Pendidikan Kimia (JPK), 81-88.

Dorsah, P., \& Yaayin, B. (2019). Altering Students' Misconceptions in Electrochemistry Using Conceptual Change Texts. International Journal Of Innovative Research and Development.

Farida, M. (2018). Bidang Kajian dan Model-model Penelitian Pendidikan Kimia. Bandung: LP2M. 
Helsy, I., Maryamah, Farida, I., \& Ramdhani, M. A. (2017). Volta-Based Cells Materials Chemical Multiple Representation to Improve Ability of Student Representation. Journal of Physics: Conf. Series, 895.

Inayati, R., \& Sukarmin. (2014). Pengembangan Multimedia Interaktif Voltachem Untuk Mengurangi Miskonsepsi Pada Sub Materi Pokok Sel Volta. UNESA Journal of Chemical Education, 3541.

Irawan, A., \& Kencanawaty, G. (2016). Peranan Kemampuan Verbal Dan Kemampuan Numerik Terhadap Kemampuan Berpikir Kritis Matematika. Aksioma: Jurnal Program Studi Pendidikan Matematika, 110-119.

Karamustafaoğlu, S., \& Mamlok-Naaman, R. (2015). Understanding Electrochemistry Concepts using the Predict-ObserveExplain Strategy. Eurasia Journal of Mathematics, Science \& Technology Education, 923-936.

LIN, H.-S., YANG, T. C., CHIU, H.-L., \& CHOU, A. C.-Y. (2002). Students' Difficulties in Learning Electrochemistry. Proc. Natl. Sci. Counc. ROC(D), 100-105.

Nisa, N. A., \& Fitriza, Z. (2021). Identifikasi Miskonsepsi Siswa Menengah Atas (SMA) Pada Pembelajaran Kimia Materi Redoks dan Elektrokimia: Studi Literatur. EDUKATIF: JURNAL ILMU PENDIDIKAN, 1191 - 1198.

Rokhim, D. A., Syafruddin, A. B., \& Widarti, H. R. (2020). Analysis of Need for Teaching Materials Based STEM-PjBL Assisted by Instructional Videos on Topic Voltaic Cells. Pedagogia: Jurnal Pendidikan.

Setiawan, N. C., Dasna, I. W., \& Muchson, M. (2020). Pengembangan Digital Flipbook untuk Memfasilitasi Kebutuhan Belajar Multiple Representation pada Materi Sel Volta. Hydrogen: Jurnal Kependidikan Kimia, 107-115.

Supasorn, S. (2015). Grade 12 students' conceptual understanding and mental models of galvanic cells before and after learning by using small-scale experiments in conjunction with a model kit. Chemistry Education Research and Practice, 393.

Treagust, D. F. (2006). Diagnostic assessment in Science as a means to improving teaching, learning and retention. UniServe Science Assessment Symposium Proceedings, (pp. 1-9). Australia.

Yunita. (2014). Model Pembelajaran Prediksi, Observasi, Dan Eksplanasi (Poe) Pada Pembelajaran Konsep Sel Volta. Jurnal Pengajaran Matematika dan Ilmu Pengetahuan Alam (JPMIPA) or Journal of Mathematics and Science Teaching, 241-247. 